\title{
Factors affecting financial inclusion in transitional country: A case of Vietnam
}

\author{
Do Hoai Linh ${ }^{1}$, Ngo Thanh Xuan ${ }^{2}$, Luu Tuan Linh ${ }^{3}$, Cao Thu Thủy ${ }^{4}$ \\ ${ }^{1}$ Associate Professor, Dr (Economics), Lecturer and Researcher, Deputy Head of Department of Banking Management, \\ School of Banking and Finance, National Economics University; linhdh@neu.edu.vn ; linhdo.neu@ gmail.com \\ ${ }^{2}$ MBA, Lecturer and Researcher, Department of Financial and Monetary Theory, School of Banking and Finance, National \\ Economics University; xuantn@neu.edu.vn \\ ${ }^{3} \operatorname{Dr}$ (Economics), Director of Strategic Planning and Board of Director Secretariat Joint Stock Commercial Bank for \\ Foreign Trade of Vietnam (Vietcombank); linhlt.ho@vietcombank.com.vn; tuanlinhcp@gmail.com \\ ${ }^{4}$ International School of Management and Economics, National Economics University; thuy2.caothu @live.uwe.ac.uk
}

Corresponding author: Cao Thu Thủy; thuy2.caothu@live.uwe.ac.uk

207 Giai Phong Road, Hai Ba Trung District, Hanoi City, 100000, Vietnam

Received 09 December 2019;

Accepted 17 December 2019;

Published 31 December 2019

\begin{abstract}
The authors aim at investigating factors driving and hindering financial inclusion in Vietnam. The dataset was achieved from the 2017 Global Financial Inclusion (Global Findex) Database of Vietnam along with two probit regressions were used to indentify factors driving access to formal financial system. The results showed that key obstacles to have a formal account are income shortage, education attainment, geographical location and individual perceptions. Converserly, age made a huge indicator of usage of formal financial services. Based on these findings, some recommendations were proposed to enhance financial inclusion for people in emerging countries such as Vietnam.
\end{abstract}

Keywords: Financial Inclusion, Transitional Country, Income Shortage, Education Attainment, Geographic, Individual Perceptions, Age

\section{Introduction}

Access to financial products and services are evidenced by both empirical analysis and random controlled experiments to be positively influenced on the economy. In terms of macroeconomic level, financial sector deepening has been brought several positive effects to the growth and stability of the economy, especially in developing economies (King and Levine, 1993; Calderón and Liu, 2003; Juzhong Zhuang et al., 2009; Anwar and Nguyen, 2011; Pasali, 2013). Existing researches also associated financial access with a decline in poverty in rural areas (Honohan, 2004; Burgess and Pande, 2005) and a soaring in levels of income (Li et al., 2001; Bruhn and Love, 2009). In terms of microeconomic level, financial services' access has a positive connection with the improvement in consumption, welfare, and commercial activities (Banerjee and Duflo, 2011; Dupas and Robinson, 2013).

Acknowledging the advantages that the access to financial products and services provide, global leaders and many national governments start taking action to facilitate the financial inclusion agenda. Internationally, heads of government and governors of central bank from 19 countries and the European Union has proposed the Financial Inclusion Action Plan (FIAP) and launched the Global Partnership for Financial Inclusion (GPFI) as commitments to alleviate financial inclusion which is beneficial for all nations and individuals, even for underserved groups (people who live in geographical isolated areas, ethnic minority, women, the poverty-stricken and youth, for instance) and vulnerable groups (which is the elder, migrants and forced displaced ones) (GPFI, 2017). Regionally, among the Association of Southeast Asian Nations (ASEAN), the vital of the issue is also recognized. The Yangon Outcomes for Financial Inclusion in ASEAN was reported from the ASEAN Financial Inclusion Conference which was held in Myanmar in October 2014. The document recommended that financial inclusion should be further as an objective of the policy beneath the Equitable Economic Development - one of the key four pillars of the ASEAN Economic Community (AEC) Blueprint (ASEAN, 2014). Nationally, a large number of countries within the community including Vietnam encourage financial inclusion by designing policies for their own economies. The State Bank of Vietnam - the central bank of the country, has been cooperating with the World Bank since 2016 in order to develop an inclusive approach for financial inclusion which will lead to a national financial inclusion strategy (NFIS). While the strategy is currently under formulating, it is expected to provide individuals and businesses a more convenient and affordable access to financial products and services, resulting in an increase in efficiency, economic development and a decline in poverty (Pazarbasioglu, 2017).

Although there are advantages of financial inclusion and the increasing attentiveness from global policymakers and financial sector participants, the Global Financial Inclusion (Global Findex) 
database pointed out that there are roughly 1.7 billion unbanked adults from 148 countries participating in the survey that does not have an account at a formal financial institution in 2017. While the percentage of the account ownership is quite large among countries with high-income (94 percent of adults), the corresponding term in developing countries is remarkably low which is about 63 percent (Demirguc-Kunt et al., 2018). It implies that most of the unbanked adults are concentrated on less developed countries. With rising evidence of advantages of financial inclusion, an essential policy question is how to improve the expansion of formal financial services. This study investigates the aforementioned question in a comprehensive manner by spotting determinants and barriers driving the access to formal financial system in terms of having an account in a bank or a formal financial institution using individuallevel dataset in Vietnam.

By determining factors driving or hindering financial inclusion in Vietnam, this paper makes several succeeding contributions for existing studies. Firstly, the financial inclusion issue is analyzed in an uncommon setting in which the economy and the financial sector are both in the process of transformation - from one of the poorest countries into a lower middle-income one, and in which the strategy for financial inclusion are mainly managed by the government and non-governmental organizations (NGOs) in collaboration. Secondly, the paper uses a well-supplied dataset that asks questions in various perspectives of the financial lives of respondents. Such diversified information from the demand side is quite challenging to obtain as Vietnam have just started to pay close attention to the financial inclusion in recent years. Owing to the dataset, this paper is capable to examine whether the factors driving or preventing access to formal financial system arise from constrains in infrastructure, and/or awareness of individuals. The achieved outcomes of this paper can be used as the basis for further study of researchers and policymakers in order to foster the strategy for financial inclusion in related settings.

\section{Literature Review}

\subsection{Definitions of financial inclusion}

Financial inclusion is not a completely new concept; however, the definition of the concept has been demonstrated variously among existing studies. Some studies defined the inclusion concept with regard to the financial exclusion concept that refers to wider context included social inclusion. Leyshon and Thrift (1995) indicated to the processes preventing several groups in the society (low-income and disadvantaged people, for instance) from approaching the financial system, whilst Sinclair (2001) defined it as the inability to have a proper form of access to essential financial services. However, many authors generate direct definitions for financial inclusion. According to Amidžić et al. (2014), it is an economic state in which individuals and businesses are not rejected to approach fundamental financial services. World Bank (2018) stated that it refers to the ability to access low-cost and convenient financial products and services of individuals and businesses that fulfill their needs that are responsibly and sustainably provided. In this research, the financial inclusion definition would be in regarded to the definition of Sarma (2008) which denoted it as "a process that ensures the ease of access, availability and usage of the formal financial system for all members of an economy". This definition provides three key dimensions namely accessibility, availability and usage - which together contributed to a complete inclusive financial system. Also, separately stating key dimensions would make the concept be less complicated to discuss.

\subsection{Factors affecting financial inclusion}

Because of these aforementioned studies, the essential policy question for Vietnam is in what ways the country can enhance its low level of access to formal sources of finance. Many existing literature on access indicates that financial access is not only about availability of institutions but also a synergy of both supply and demand sides (Claessens, 2005; Beck et al., 2008). According to Campero and Kaiser (2013), the availability of financial products and services are determined by components of the supply side and at the same time, the usage of these products and services are driven by components of the demand side. In terms of financial inclusion, constrains in data had implied that components of the supply side were more studied than demand side components, requiring the availability of more comprehensive data in individual-level, and, as a consequence, the influence of individual-level determinants on access to formal sources of finance are initiating to be estimated. Though demand side components in the individual level have been less investigated, many literatures have examined impacts of socio-economic components on access to financial product and services.

Components of socio-economic which are often investigated are age, gender, income, educational attainment, and employment condition. In the study of Zins and Weill (2016), the probability of being financially included of adults is found to be increased along with their ages, but after reaching a specific age, this probability declines. Income and educational attainment are frequently found to be significant with financial access. Some other components such as gender and employment condition have been stated to have a positive relation in several works (Milton, 2008; Fungáčová and Weill, 2014; Peña et al., 2014). By analyzing socio-economic characteristics of individuals globally, Allen et al. (2016) reveals that the likelihood of having an account in a bank of other form of formal financial institution is higher with adults who are older, richer, attain more in education. These adults also tend to be employed, married or separated and live in urban areas. In the study case of China, adults who are male, older, married, earn more and educated have more tendency of being financially included (Fungáčová and Weill, 2014). By using financial inclusion data of 98 developing countries, Demirguc-Kunt et al. (2013) indicate that there is a gender gap in the financial inclusion. Being a female would make the likelihood of being financially included from formal sources lower than being a male because they have to deal with higher hardship to provide vital documentation or collateral and lower financial knowledge. However, this finding is inconsistent across country. Allen et al. (2016) find that on the global scale, there is an insignificant gap between genders in account ownership. Moreover, other cross-country outcomes point out that the degree of the influence of the aforementioned components on access to formal financial institutions divers among countries (Honohan and King, 2009), and that formal account ownership and usage are linked with particular characteristics of a country such as bank account fees and closeness to financial institutions (Allen et al., 2016).

Besides factors driving account ownership and usage of products and services from formal financial institutions, several papers have also studied barriers to access formal sources of finance. By studying a specific case namely China, Fungáčová and Weill (2014) investigate the relationship between characteristics of individual and situation of not having an account in formal institutions. They discover that income and age are connected with some reasons of not having an account, whilst gender and educational attainment are related to fewer reasons. Specifically, in the matter of barriers to formal financial access, poorer people are 
more concern about their money insufficiency and the fact that other family members already has a formal account, whilst adults who are more educated pay more attention to costs of using financial services and trust in the formal financial system. As well, Fungáčová and Weill (2014) finds out that the probability of women owning a formal account is less than men due to the fact that they do not have enough vital documentation or there is another member in the family already own one. Finally, older people are care more about lack of money, the proximity of financial institutions and religious reasons. Income and educational attainment are identified by authors to be factors influencing the decision between using formal and informal credit of Chinese people; however, the educational attainment does not result in higher formal credit. By analyzing global cross-nation individuallevel dataset, Allen et al. (2016) indicated that factors hindering account ownership comprise costs, lack of essential documentation, distance to formal financial institution, and money insufficiency. Moreover, Harriss et al. (1998) points out that individuals rely on their metal models to decide whether or not to use formal financial services. Hence, individual perceptions might be a factor hindering people from participating in formal sources of finance. Nevertheless, the degree to which different explanations for usage of formal sources of finance relies on particular individual traits.

In brief, the existing studies on financial inclusion denote that there are many advantages related to formal financial inclusion, specifically the ownership and usage of formal products and services. Additionally, an examination of demand-side studies unveils that several individual-level socio-economic characteristics influence on the uptake and usage of formal sources of finance. From the viewpoint of people who are being excluded formally, barriers that they have to deal with are costs of possessing an account, essential documentation shortage, distance to formal financial institutions, and money insufficiency. Such barriers, in combination with individual-specific characteristics, determine exclusion of formal sources of finance among individuals.

\section{Methodology}

The used dataset was achieved from the 2017 Global Financial Inclusion (Global Findex) Database of Vietnam. Global Findex Vietnam is a nationally representative survey which is designed and conducted once every 3 years by the World Bank and Gallup Incorporation together since 2011 in order to provide a better insight for policymakers, researchers and entrepreneurs of how individual adults manage their finances day within the nation. Additionally, the dataset can be utilized to determine gaps in formal financial institutions' access and from that authorities are able to adjust policies to boost financial inclusion of the country. The survey was conducted face-to-face randomly with 1002 Vietnamese adults in 52 over 63 provinces from September to October 2017. The included provinces account for approximately $81 \%$ of the population of Vietnam.

In order to indentify factors driving access to formal financial system, two probit regressions are used with slightly different variables. The equation in general is presented as follows:

$$
X_{i}=\alpha+\beta_{1} \text { female }_{i}+\beta_{2} a g e_{i}+\beta_{3} a g e_{-} s q_{i}+\beta_{4} e d u c_{i}+\beta_{5} i n c_{-} q_{i}+\beta_{6} e m p_{-} i n_{i}
$$

In the general equation, i represents one given adult individual. In both models, there a dependent variable which is included to find out whether participant has an account in banks or other formal financial institutions $(\mathrm{X})$. Additionally, six independent variables which represent socio-economic characteristics of participant namely gender (whether respondent is male of female), age, age squared (inserted to model more precisely the impact of age), education attainment, within-economy income group and employment status are added in Model 1. In Model 2, there are differences with regard to education attainment and income variables. These two are included as series of indicator variables: educational attainment are classified into five levels and the lowest level will be set as the basis for the other three indicators in order to examine influences on the dependent variable of each level. Similar with education, income is also categorized as 5 groups of indicators and the lowest group acts as the basis to investigate impacts on dependent variable. As coefficients of the probit model are usually difficult to interpret directly, marginal effects are also reported in order to measure the discrete change of the outcome (dependent variable) when an explanatory variable (independent variable) changes, if other variables remain unchanged.

To discover the key barriers that hinders access to formal financial institutions of respondents, a qualitative analysis was conducted. The sub-sample for investigation of barriers in access only consists of respondents who do not have an account in formal financial system at the time the survey conducted. Qualitative information is obtained for this sub-sample so that the key causes for financial inclusion are identified. The data used in this qualitative analysis is extracted from the question on the Global Findex questionnaire which asks participants who did not have an account to provide reasons for not having one.
Table 1: Description of Variables

\begin{tabular}{|c|c|}
\hline Variables & Description \\
\hline \multicolumn{2}{|c|}{ Dependent Variable } \\
\hline account_fin & $\begin{array}{l}\text { Dummy }=1 \text { if respondent has an account in } \\
\text { banks or other formal financial institutions }\end{array}$ \\
\hline \multicolumn{2}{|c|}{ Socio-economic Characteristics } \\
\hline female & Dummy $=1$ if respondent is female \\
\hline age & Age of respondent (in years) \\
\hline age_sq & Age squared of respondent \\
\hline $\begin{array}{l}e d u c \\
e d u c \_p r i m \\
e d u c \_s e c \\
e d u c \_t e r \\
e d u c \_d k \\
e d u c \_r s\end{array}$ & $\begin{array}{l}\text { Education level of respondent (series of } \\
\text { indicator variables): } \\
\text { 1. Completed primary or less secondary } \\
\text { 2. Secondary } \\
\text { 3. Completed tertiary or more } \\
\text { 4. Do not know } \\
\text { 5. Refuse to provide information } \\
\end{array}$ \\
\hline $\begin{array}{l}\text { inc_q } \\
\text { inc_poor } \\
\text { inc_sec } \\
\text { inc_mid } \\
\text { inc_fourth } \\
\text { inc_rich }\end{array}$ & $\begin{array}{l}\text { Within-economy household income quintile of } \\
\text { respondent } \\
\text { 1. Poorest } 20 \% \\
\text { 2. Second } 20 \% \\
\text { 3. Middle } 20 \% \\
\text { 4. Fourth } 20 \% \\
\text { 5. Richest } 20 \%\end{array}$ \\
\hline emp_in & $\begin{array}{l}\text { Dummy = } 1 \text { if respondent are currently in } \\
\text { workforce }\end{array}$ \\
\hline
\end{tabular}

\section{Results and discussion}

\subsection{Factors driving formal financial inclusion}

Table 2: Summary Statistics

\begin{tabular}{|l|l|l|l|l|}
\hline Variables & Mean & Std.Dev. & Min & Max \\
\hline Dependent Variable & 0.327 & 0.469 & 0 & 1 \\
\hline account_fin & 0.45 & \\
\hline Socio-economic Characteristics \\
\hline female & 1.574 & 0.495 & 1 & 2 \\
\hline
\end{tabular}




\begin{tabular}{|l|l|l|l|l|}
\hline Age & 42.366 & 16.222 & 15 & 91 \\
\hline age_sq & 2057.768 & 1522.802 & 225 & 8281 \\
\hline Educ & 1.858 & 0.76 & 1 & 5 \\
\hline inc_q & 3.17 & 1.437 & 1 & 5 \\
\hline emp_in & 0.743 & 0.437 & 0 & 1 \\
\hline
\end{tabular}

Table 2 presents summary of descriptive statistics for the socioeconomic characteristics of adult individual. The results of the two probit regressions are reported in Table 3. The outcomes from the econometric analysis provide information on the factors driving formal financial inclusion with regard to account ownership. Socio-economic characteristics of respondent which are indicated to be vital for formal access are age, income and educational attainment. In terms of age, this characteristic appears to be significant. By looking at the positive coefficient of age variable and the negative one of age squared variable in both models, it implies that the likelihood of having an account at formal institutions rise along with age of respondent until a turning point is attained, and the probability begins to decline after that point. The turning point can be roughly estimated by dividing negative coefficient value of age for two times coefficient value of age squared. The equations of two models are presented as below. The results indicate that the probability of having an account starts decreasing at 30.94 years of age onwards in Model 1, while the turning point in Model 2 is 35.03 years old.

$$
\begin{aligned}
& \text { Turning point in Model } 1=\frac{-\beta_{\text {age }}}{2 \beta_{\text {age }} \text { sq }}=\frac{-0.0393}{2 *(-0.000635)}=30.94 \text { years of age } \\
& \text { Turning point in Model } 2=\frac{-\beta_{\text {age }}}{2 \beta_{\text {age }}}=\frac{-0.0468}{2 *(-0.000668)}=35.03 \text { years of age }
\end{aligned}
$$

\begin{tabular}{|c|c|c|c|c|}
\hline \multirow[b]{2}{*}{ VARIABLES } & \multicolumn{2}{|l|}{ MODEL 1} & \multicolumn{2}{|l|}{ MODEL 2} \\
\hline & Coefficients & Marginal Effects & Coefficients & Marginal Effects \\
\hline \multirow[t]{2}{*}{ female } & 0.00437 & 0.00135 & 0.0274 & 0.00800 \\
\hline & $(0.0890)$ & $(0.0274)$ & $(0.0914)$ & $(0.0267)$ \\
\hline \multirow[t]{2}{*}{ age } & $0.0393 * *$ & $0.0121 * *$ & $0.0468 * *$ & $0.0137 * *$ \\
\hline & $(0.0180)$ & $(0.00551)$ & $(0.0186)$ & $(0.00540)$ \\
\hline \multirow[t]{2}{*}{ age_sq } & $-0.000635 * * *$ & $-0.000195 * * *$ & $-0.000668 * * *$ & $-0.000195 * * *$ \\
\hline & $(0.000207)$ & $(6.32 \mathrm{e}-05)$ & $(0.000215)$ & $(6.22 \mathrm{e}-05)$ \\
\hline \multirow[t]{2}{*}{ educ } & $0.504 * * *$ & $0.155^{* * *}$ & & \\
\hline & $(0.0603)$ & $(0.0167)$ & & \\
\hline \multirow[t]{2}{*}{ educ_sec } & & & $0.735 * * *$ & $0.211 * * *$ \\
\hline & & & $(0.115)$ & $(0.0298)$ \\
\hline \multirow[t]{2}{*}{ educ_ter } & & & $1.609 * * *$ & $0.530 * * *$ \\
\hline & & & $(0.156)$ & $(0.0471)$ \\
\hline \multirow[t]{2}{*}{$e d u c \_d k$} & & & 0.252 & 0.0601 \\
\hline & & & $(0.572)$ & $(0.151)$ \\
\hline \multirow[t]{2}{*}{ educ_rs } & & & -0.103 & -0.0204 \\
\hline & & & $(0.577)$ & $(0.109)$ \\
\hline \multirow[t]{2}{*}{$i n c \_q$} & $0.117 * * *$ & $0.0361 * * *$ & & \\
\hline & $(0.0320)$ & $(0.00964)$ & & \\
\hline \multirow[t]{2}{*}{ inc_sec } & & & 0.0961 & 0.0270 \\
\hline & & & $(0.161)$ & $(0.0451)$ \\
\hline \multirow[t]{2}{*}{ inc_mid } & & & 0.142 & 0.0404 \\
\hline & & & $(0.160)$ & $(0.0452)$ \\
\hline \multirow[t]{2}{*}{ inc_fourth } & & & 0.251 & 0.0729 \\
\hline & & & $(0.154)$ & $(0.0444)$ \\
\hline \multirow[t]{2}{*}{ inc_rich } & & & $0.383 * *$ & $0.114 * * *$ \\
\hline & & & $(0.150)$ & $(0.0440)$ \\
\hline \multirow[t]{2}{*}{ emp_in } & 0.173 & 0.0533 & 0.141 & 0.0412 \\
\hline & $(0.116)$ & $(0.0356)$ & $(0.118)$ & $(0.0345)$ \\
\hline \multirow[t]{2}{*}{ Constant } & $-2.355 * * *$ & & $-2.110 * * *$ & \\
\hline & $(0.418)$ & & $(0.419)$ & \\
\hline Observations & 1,000 & 1,000 & 1,000 & 1,000 \\
\hline
\end{tabular}

Table 3: Results from two Probit Regressions

Standard errors in parentheses, $* * * p<0.01, * * p<0.05, * p<0.1$

In terms of income, the coefficient and marginal effect of this variable in Model 1 are both statistically significant. It means that the higher the income of respondent, the higher the likelihood of having an account in a formal financial institution. This is consistent with the achieved results of several existing studies (Fungáčová and Weill, 2014; Allen et al., 2016). In Model 2, the relationship between income group and account ownership are examined in detail. With the group of the poorest $20 \%$ acts as the basis, the second, middle and fourth groups of income are not significant determinants of formal account ownership. However, the income group of 20-percent richest strongly influences on account ownership. The positive marginal effect points out that the predicted probability of having a formal account of respondent whose income is in 20-percent richest is 11.4 percentage points higher than those with income belongs to the group of 20-percent poorest.

In terms of education, the estimated values of coefficients and marginal effect are statistically significant in the Model 1. It 
implies that the likelihood of having a formal account increases if respondent has higher attainment level in education. Specifically, people who completed secondary school are more likely own an account in formal sources of finance in comparison with those who only finished primary school. The effect is even stronger if the highest educational attainment of respondent is tertiary and more. The predicted probability of having a formal account of tertiarylevel respondent is 53 percentage point higher compared to primary-level respondent. These achieved results are consistent with some existing researches which stated that income and educational level are important factors driving formal financial inclusion (Fungáčová and Weill, 2014; Peña et al., 2014).

In terms of employment, both values of coefficient and marginal effect are statistically insignificant. This is also happened to the coefficient value of female variable. These results imply the fact that employment status and gender are not the key explanations of the likelihood of having a formal account of respondent in Vietnam. The finding in gender effect is relatively similar with the findings of Allen et al. (2016).

\subsection{Factors hindering formal financial inclusion}

In this section, explanations for decisions of not owning an account in formal institution will be provided. Outcomes from Global Findex survey for Vietnam points out that only approximately $31 \%$ of adults had an account in formal financial institutions and $21 \%$ of adults borrow from formal financial institutions. This means the majority of Vietnamese population remained unbanked and borrowed from informal sources of finance at the time the survey was carried on in 2017. These figures show a higher level of exclusion financially in comparison with several Southeast Asia peers. For example, according to similar survey conducted by World Bank in the neighboring Thailand, the percentage of its population possessing a formal account was impressively high, at $82 \%$, while the formal borrowing proportion was surprisingly low which was $15 \%$. With regard to Malaysia, the large part of its population were own an account in formal financial institutions ( $82 \%$ of adults) and only $12 \%$ of adults borrowed from formal sources (World Bank, 2017a).

Table 4: Reasons for Not Having an Account

Ask if respondent do not have not have account

Why do you, personally, do not have an account in a bank or other type of formal financial institutions?

\begin{tabular}{l|l}
\hline $\mathbf{1}$ & Financial institutions are too far away \\
\hline $\mathbf{2}$ & Financial services are too expensive
\end{tabular}

2 Financial services are too expensive

3 Do not have the necessary documentation

$\mathbf{4}$ Do not trust financial institutions

\begin{tabular}{|l|l|}
\hline $\mathbf{5}$ & Religious reasons \\
\hline
\end{tabular}

\begin{tabular}{lll}
$\mathbf{6}$ & Lack of money to use financial institutions \\
\hline 7 & Other family member
\end{tabular}

\begin{tabular}{l|l}
$\mathbf{7}$ & Other family member already has an account \\
\hline $\mathbf{8}$ & No need for
\end{tabular}

$\mathbf{8} \quad$ No need for financial services at a formal institution

Table 4 showed the question used to identify reasons why some Vietnamese adults do not own a formal account and its options.

When required to provide the key reason for not having a formal account, $29.62 \%$ of the respondents answered that they had no demand for financial services at a formal institution, making this option become the most chosen reason for not own any formal account. The second chosen for the formal account shortage is that they were lack of money to use financial institutions (28.89\%). The third most-cited explanation is that there was other member in the family that already has a formal account (13.62\%). Those who thought the distance to banks or other formal financial institutions were too far comprise $8.10 \%$. Some other respondents refused to access formal sources due to their lack of vital documentation $(7.45 \%)$, high costs of financial services $(6.90 \%)$ and their lack of trust for these institutions (5.15\%). Only a small fraction of the answers which were $0.28 \%$ chose explanation related to religious

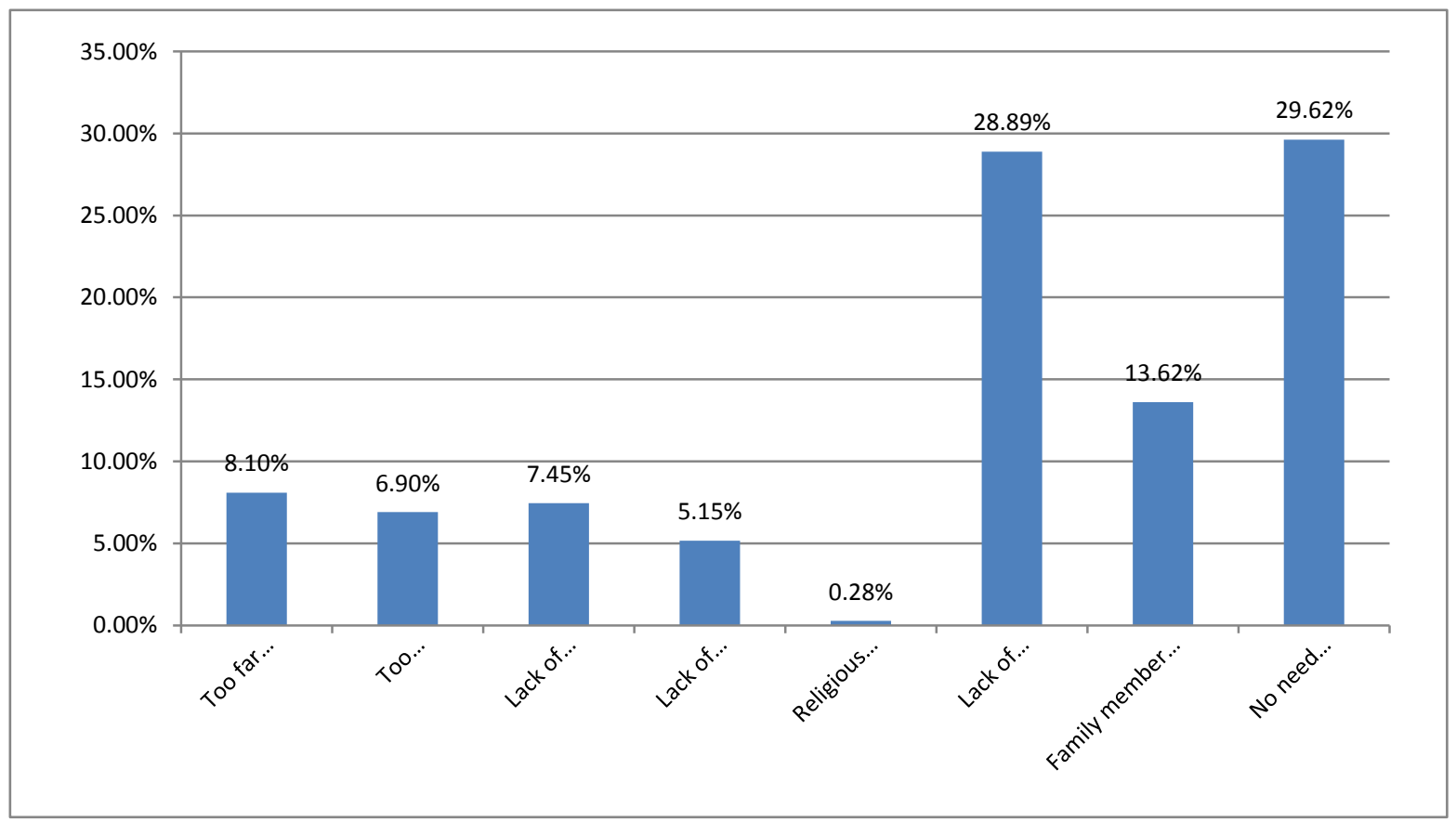

Data source: World Bank (2017a)

Fig 1: Main Reasons for Not Having an Account (in \%)

When examining the socio-economic characteristics of the subsample of participators who had not own a formal account at the conducted time of the Global Findex survey, the date reveals that adults who not have an account in banks or other formal financial institutions have tendency of being those who were middle-aged and old people, and have lower attainment of education, lower regular income in comparison to those who have a formal account. Nevertheless, several other factors namely gender and status of 
employment are similar among adults who own an account and those who do not. These findings of this study about factors hindering access to formal sources of finance are consistent with some existing literature (Fungáčová and Weill, 2014; Allen et al., 2016).

\subsection{Discussion}

The study found that age is a factor that significantly influences on the access to formal financial institutions. The likelihood of access formal source increases when people get older. However, the effect stops soon at approximately 30 years of age and the likelihood diminishes after that. It means that people who above 30 years old will have lower access. In addition, the population of Vietnam started appearing sign of aging. An aging population will cause even lower access to formal sources of finance. A decline in GDP per capital growth rate of the country is also expected (if there is no improvement in labor productivity) when the population is getting older and older (Viet Nam Institue for Development Strategies, 2016). Therefore, this factor should be considered by policymakers when formulating national financial inclusion strategy.

As can be seen from achieved results from econometric and quantitative analysis, income affects the inclusion both positively and negatively. If incomes of individuals are increased, there is high chance that they will take part in the formal financial system. As mentioned in the literature review, higher access would increase their savings, financially support in short-term shocks and promote participation in productive activities (Park and Mercado, 2015), leading to an improvement of the financial sector and contributing to the economic growth of a country (Beck and Demirgüç-Kunt, 2008). However, if the incomes decrease, the effect will be transmitted in the opposite mechanism which ultimately results in a fall in the economic growth of the country. Therefore, Vietnamese authorities have made an attempt to boost the income of adults in the country. Due to the database of CEIC (2018), the average monthly income level of Vietnamese has increased roughly three times in ten years (2008-2017). This increasing in income has led to improvement in access to formal financial system and the growth of the economy of Vietnam in the last few years.

The socio-economic characteristic namely education attainment is also an important factor with regarding to formal financial access. The lower the educational level of individuals, the lower the probability of involving in the formal financial system of them. The higher educated adults are more likely to understand the advantages of access formal sources of finance compared to low educated ones. By looking at the information provided in the dataset, it can be seen that a large part of adults have lower attainment in education. A low-educated population would not increase access to the formal financial system and make the economy of the country develop in a sustainable way as each citizen is lack of essential knowledge and skills to foster themselves and contribute to the country. As a result, Vietnamese government has been striving to improve education of its citizens to the tertiary level. Within a decade from 2005 to 2015, the proportion of students enrolling in higher education institutions have almost doubled, from $16 \%$ to $29 \%$ (PwC, 2017). This improvement has not seen a sign of stopping. The access to formal financial institutions of individuals and the economic growth has also increased in this period of time so that the findings of this study are consistent with economic theory and real situations of the country.
Due to the fact that roughly two third of the population do not have access to formal sources of finance, they consequently tend to use informal finance sources (moneylenders, rotating savings and credit associations and pawnshops, for example). As there is seriously lack of studies related to informal finance institutions in Vietnam, most of the explanation hereafter would be mainly based on individual observations and information from newspapers. This type of financial institutions is often favored by many adults (especially poor people) because of their simple borrowing procedure, no collateral requirement and immediate handing money. However, they are usually charge ridiculously high interest to cover up the costs of providing immediate loans which could make borrowers unable to pay the money back. If the borrowers pay the periodical interest late or have intention to default, they would even threaten, assault or steal the properties of borrowers (Viet Nam News, 2018). Therefore, this informal finance leads to the turbulence in the society. Not only that, it also affects the economy of the country. A considerable amount of money is in the hands of these institutions rather than in the formal financial system, influencing on the money supply for sectors in the economy.

\section{Recommendations and Conclusion}

In order to boost financial inclusion regarding to account ownership, findings from this study recommend that programs of financial inclusion and financial literacy that permit individuals understand their financial situations should be held. Nearly one third of the surveyed respondents reported that they have no need for financial services; most of these respondents are low-educated. This lack of demand might arise from the lack of awareness of respondents. They might not recognize or understand the benefits they could receive when having access to formal sources of finance. Therefore, holding financial literacy is important in order to raise awareness related to advantages of using formal sources of finance to adults.

Many respondents participated in the survey answered that they are do not have enough money so that they do want to use formal financial institutions. Besides low income, lack of financial management skill could be an explanation for this circumstance. Because of experience of some other nations, adults who are aware of recording their finances tend to spend more thoroughly, leading to a falling in expenses. In the case that their incomes might not be raised, declined expenses mean that they have more money left to be saved and they are now able to use formal financial services (Tambunlertchai, 2017). For a nation with such a high rate of literacy like Vietnam (CFI, 2018), encouraging adults take part in financial literacy programs which provide essential financial knowledge and skills in order to help participators learn how to manage their finances wisely could lead to a rising in access to formal financial institutions in the national scale.

The findings of this study indicate that physical access to formal sources of finance could be increased by enhancing infrastructure such as establish more branches or transaction offices of formal institutions. Alternative channels that could alleviate access consist of setting up mobile bank branches namely trucks and vans to approach better people in rural and remote areas. As the rates of internet connectivity and mobile phone penetration in Vietnam is relatively high even in rural areas in comparison with several other countries in the region, the authorities could utilize this to set up the foundation for mobile phone banking to promote usage of formal sources of finance. These aforementioned instances have been conducted in different countries and have succeed to improve 
the approach level of formal sources of finance for individuals and households in remote areas who are lack of convenient access to formal financial institutions physically.

Because Vietnam continues to transform the financial sector toward the direction of expanding financial inclusion, and because the economy of Vietnam as a whole has strong potential to growth even more, some remarkable enhancements in the sector and in socio-economic characteristics are expected to be occurred in the next few years. The economy growth is expected to cause an increase in income, implementations of fostering financial inclusion is believed to lead to a wider range of financial system that provide more suitable products and services for low-income adults specifically. These forces, in combination with comprehensive demand-side investigations of financial inclusion, set the scene for a rise in the level of access formal financial institutions for adults who used to be financially excluded.

\section{Conflicts of Interest}

The authors declare that there is no conflict of interest regarding the publication of this paper.

\section{Funding Statement}

The research and publication of our article was funded by owned finance of authors.

\section{References}

[1] ADB 2019. Asian Development Outlook (ADO) 2019: Strengthening Disaster Resilience. Philippines: Asian Development Bank.

[2] ALlEN, F., DEMIRGUC-KUNT, A., KLAPPER, L. \& PERIA, M. M. 2016. The foundations of financial inclusion: Understanding ownership and use of formal accounts. Journal of Financial Intermediation, 27, 1-30.

[3] AMIDŽIĆ, G., MASSARA, A. \& MIALOU, A. 2014. Assessing Countries' Financial Inclusion Standing-A new Composite Index.

[4] ANWAR, S. \& NGUYEN, L. P. 2011. Financial development and economic growth in Vietnam. Journal of Economics and Finance, 35, 348-360.

[5] APORTELA, F. 1999. Effects of Financial Access on Savings by Low-Income People. MIT Department of Economics Dissertation Chapter 1 [Online]. Available: http://citeseerx.ist.psu.edu/viewdoc/download?doi=10.1.1.194 $.5270 \&$ rep=rep1\&type=pdf [Accessed 30 November 2018].

[6] ASEAN. Yangon Outcomes for Financial Inclusion in ASEAN. ASEAN Financial Inclusion Conference, 2014 Yangon, Myanmar.

[7] BANERJEE, A. \& DUFLO, E. 2011. Poor Economics: A Radical Rethinking of the Way to Fight Global Poverty, PublicAffairs.

[8] BECK, T. \& DEMIRGÜÇ-KUNT, A. 2008. Access to Finance. World Bank Economic Review, 22, 383-396.

[9] BECK, T., DEMIRGÜÇ-KUNT, A. \& PERIA, M. S. M. 2008. Banking Services for Everyone? Barriers to Bank Access and Use around the World World Bank Economic Review, 22, 397-430.

[10] BRUHN, M. \& LOVE, I. 2009. The economic impact of expanding access to finance in Mexico. Finance \& PSD impact evaluation note. Washington, DC: World Bank.
[11] BURGESS, R. \& PANDE, R. 2005. Do Rural Banks Matter? Evidence from the Indian Social Banking Experiment. American Economic Review, 95, 780-795.

[12] CALDERÓN, C. \& LIU, L. 2003. The direction of causality between financial development and economic growth. Journal of Development Economics, 72, 321-334.

[13] CAMPANARO, A. \& DANG, C. D. 2018. Mobilizing Finance for Local Infrastructure Development in Vietnam: A City Infrastructure Financing Facility. Washington, DC: World Bank.

[14] CAMPERO, A. \& KAISER, K. 2013. Access to Credit: Awareness and Use of Formal and Informal Credit Institutions. Working Papers. Banco de México.

[15] CEIC 2018. Vietnam Average Monthly Income: Overall.

[16] CFI. 2018. Overview of Banks in Vietnam [Online]. Coporate Finance Institute. Available: https://corporatefinanceinstitute.com/resources/careers/compa nies/top-banks-in-vietnam/ [Accessed 18 April 2019].

[17] CIA 2015. The World Factbook. Central Intelligence Agency.

[18] CLAESSENS, S. 2005. Access to financial services: a review of the issues and public policy objectives. Policy Research working paper. Washington, DC: World Bank.

[19] CLAESSENS, S. \& PEROTTI, E. 2007. Finance and inequality: Channels and evidence. Journal of Comparative Economics, 35, 748-773.

[20] DEMIRGUC-KUNT, A., KLAPPER, L. \& SINGER, D. 2013. Financial inclusion and legal discrimination against women : evidence from developing countries. Policy Research Working Paper. Washington, DC.

[21] DEMIRGUC-KUNT, A., KLAPPER, L. \& SINGER, D. 2017. Financial Inclusion and Inclusive Growth: A Review of Recent Empirical Evidence. Policy Research Working Paper

[22] DEMIRGUC-KUNT, A., KLAPPER, L., SINGER, D., ANSAR, S. \& HESS, J. 2018. The Global Findex database 2017: Measuring Financial Inclusion and the Fintect Revolution. Washington D.C: World Bank.

[23] DUPAS, P. \& ROBINSON, J. 2013. Savings Constraints and Microenterprise Development: Evidence from a Field Experiment in Kenya. AMerican Economic Journal: Applied Economics, 5, 163-192.

[24] FUNGÁČOVÁ, Z. \& WEILL， L. 2014. Understanding financial inclusion in China. BOFIT Discussion Papers. Institute for Economies in Transition.

[25] GPFI 2017. G20 Financial Inclusion Action Plan (FIAP) 2017. Global Partnership for Financial Inclusion.

[26] HARRISS, J., HUNTER, J. \& M.LEWIS, C. 1998. The New Institutional Economics and Third World Development, London, Routledge

[27] HONOHAN, P. 2004. Financial Development, Growth and Povery: How close are the Links? Policy Research Working Paper. World Bank.

[28] HONOHAN, P. \& KING, M. 2009. Cause and Effect of Financial Access: Cross-country Evidence from Finscope Surveys. Measurement, Promotion, and Impact of Access to Financial Services. Washington, DC: World Bank.

[29] JUZHONG ZHUANG, H. G., YOKO NIIMI, , MUHAMMAD EHSAN KHAN, Y. J., RANA HASAN, NINY KHOR, \& ANNELI S. LAGMAN-MARTIN, P. B., AND BIAO HUANG 2009. Financial Sector Development, Economic Growth, and Poverty Reduction: A Literature Review. ADB Economics Working Paper Series. Manila: Asian Development Bank. 
[30] KING, R. G. \& LEVINE, R. 1993. Finance and Growth: Schumpeter Might be Right. Quarterly Journal of Economics 108, 717-737.

[31] LEYSHON, A. \& THRIFT, N. 1995. Geographies of Financial Exclusion: Financial Abandonment in Britain and the United States Transactions of the Institute of British Geographers New Series, 20, 312-341.

[32] LI, H., SQUIRE, L. \& ZOU, H. F. 2001. Explaining International and Intertemporal Variations in Income Inequality. The Economic Journal, 108, 26-43.

[33] MILTON, L. 2008. Financial inclusion in the UK: Review of policy and practice. Joseph Rowntree Foundation.

[34] MOOKERJEE, R. \& KALIPIONI, P. 2010. Availability of financial services and income inequality: The evidence from many countries. Emerging Markets Review, 11, 404-408.

[35] NGUYEN, K. A., LE, T. T., NGUYEN, M. C., NGUYEN, V. T. \& NGUYEN, T. T. M. 2014. Microfinance In Vietnam: The Real Situation And Policy Recommendations. Hanoi: Vietnam Microfinance Working Group.

[36] NGUYEN, T. D. 2011. Decision on Approving the Proposal for Building and Developing the Microfinance System in Vietnam up to 2020. Hanoi: Vietnamese Government.

[37] NIELSEN 2017. Smartphone keeps up the growth momentum with increasing usage incidences in key cities; whilst rural smartphone users reaching up to $68 \%$.

[38] OXFORD BUSINESS GROUP 2017. The Report: Vietnam 2017.

[39] PARK, C.-Y. \& MERCADO, R. V. 2015. Financial Inclusion, Poverty, and Income Inequality in Developing Asia ADB Economics Working Paper Series. Manila.

[40] PASALI, S. S. 2013. Where is the cheese ? synthesizing a giant literature on causes and consequences of financial sector development. Policy Research Working Paper. Washington, DC: World Bank.

[41] PAZARBASIOGLU, C. 2017. Vietnam's financial inclusion priorities: Expanding financial services and moving to a 'noncash' economy [Online]. World Bank. Available: https://blogs.worldbank.org/voices/vietnam-s-financialinclusion-priorities-expanding-financial-services-and-movingnon-cash-economy [Accessed 4 April 2019].

[42] PEÑA, X., HOYO, C. \& TUESTA, D. 2014. Determinants of financial inclusion in Mexico based on the 2012 National Financial Inclusion Survey (ENIF). BBVA Research Working Paper. Madrid.

[43] PIMHIDZAI, O. 2018. Climbing the ladder : poverty reduction and shared prosperity in Vietnam. Washington, DC: World Bank.
[44] PWC 2017. Spotlight on Viet Nam: The leading emerging market.

[45] SARMA, M. 2008. Index of Financial Inclusion. Working Paper. New Delhi Indian Council for Research on International Economic Relations (ICRIER).

[46] SBV 2016. Financial institution system Hanoi: SBV.

[47] SEGRE, M. 2018. Financial literacy and finacial inclusion in Vietam: A way back and forth. In: MALAGARDIS, A. (ed.). Manila: Deutsche Gesellschaft für Internationale Zusammenarbeit (GIZ) $\mathrm{GmbH}$

[48] SIDDIK, N. A. 2017. Does Financial Inclusion Promote Women Empowerment? Evidence from Bangladesh. Applied Economics and Finance, 4.

[49] SINCLAIR, S. 2001. Financial Exclusion: An Introductory Survey. Report of Centre for Research in Socially Inclusive Service. Edinburgh Heriot-Watt University.

[50] SWAMY, V. 2013. Financial Inclusion, Gender Dimension, and Economic Impact on Poor Households. World Development, 56, 1-15.

[51] TAMBUNLERTCHAI, K. 2017. Determinants and barriers to financial inclusion in Myanmar: What determines access to financial services and what hinders its? Singapore Economic Review, 63, 9-26.

[52] US DEPARTMENT OF COMMERCE. 2018. Vietnam Banking Systems [Online]. US Department of Commerce. Available: https://www.export.gov/article?id=VietnamBanking-Systems [Accessed 4 April 2019].

[53] VIET NAM INSTITUE FOR DEVELOPMENT STRATEGIES 2016. Impact of changes in population age structure on Vietnam's economic growth and policy recommendations. Hanoi: Viet Nam Institue for Development Strategies.

[54] VIET NAM NEWS. 2018. Loan sharks trap poor people. Viet Nam News.

[55] WORLD BANK 2017a. Global Findex database. In: BANK, W. (ed.). Washington, DC.

[56] WORLD BANK 2017b. World Development Indicators.

[57] WORLD BANK. 2018. Financial Inclusion Overview [Online]. World Bank. Available: https://www.worldbank.org/en/topic/financialinclusion/overvi ew [Accessed 30 November 2018].

[58] ZINS, A. \& WEILL, L. 2016. The determinants of financial inclusion in Africa. Review of Development Finance, 6, 4657. 